\title{
The Research of Literary Criticism (Materialism in The Great Gatsby Novel by Fitzgerald)
}

\author{
Jaftiyatur Rohaniyah
}

\author{
Sekolah Tinggi Teknologi Nurul Jadid, Paiton, Probolinggo \\ E-mailaddress:javetien8@gmail.com
}

\begin{abstract}
:
The material as the life's necessities of human changes into prestige of the human himself. Material is no longer interpreted as the life's necessities but it changes into money. It becomes the symbol of success and happiness. This shift process certainly brings a lot of change to the human nature. Material which at the beginning is considered as the life necessities turns into human obsession to reach the happiness. In the literary criticism, materialism is one of approach to analyze the values in the literary works. Its used by Fitzgerald to view the complexity of the story in the 'Great Gatsby' Novel, but unfortunately the fact, its ironic because material satisfaction is only empty happiness as reflected in this paper.
\end{abstract}

Keywords: Materialism, The Great Gatsby Novel

\section{Introduction}

The Great Gatsby is a story of the saddened love between a man and a woman. In the matter of fact, the main theme of the novel encompasses a much larger, less romantic scope. There are some major themes of this novel but the most interesting themes of it are fall of American dream and pursuit of material as the symbols of success and happiness.

Fitzgerald portrays the 1920 s as an era of decayed social and moral values, evidenced in its overarching greed, arrogant, empty pursuit of pleasure and even ignore to other human. The reckless jubilance that led to decadent parties and wild jazz music, epitomized in The Great Gatsby by the opulent parties that Gatsby throws every Saturday night, resulted ultimately in the corruption of the American dream, as the unrestrained desire for money and pleasure surpassed more noble goals.

When World War I ended in 1918, the generation of young Americans who had fought the war became intensely disillusioned, as the 
brutal carnage that they had just faced scramble for wealth. The clash made the Victorian social morality of between "old money" and "new early twentieth century America seem money" manifests itself in the like stuffy or empty hypocrisy. The novel's symbolic geography: East dizzying rise of the stock market in Egg represents the established the aftermath of the war led to a aristocracy, West Egg the self-made sudden, sustained increase in rich. Meyer Wolfshiem and Gatsby's thenational wealth and a newfound fortune symbolize the rise of materialism, as people began to organized crime and bootlegging.

spend and consume at unprecedented As Fitzgerald saw it, the levels. A person from any social American dream was originally about background could, potentially, make discovery, individualism, and the a fortune, but the American pursuit of happiness. In the 1920s aristocracy (families with old wealth) scorned the newly rich industrialists and speculators. Additionally, the passage of the Eighteenth Amendment in 1919, which banned the sale of alcohol, created a thriving underworld designed to satisfy the massive demand for bootleg liquor among rich and poor alike.

Fitzgerald positions the characters of The Great Gatsby as emblems of these social trends. Nick and Gatsby, both of whom fought in World War I, exhibit the newfound cosmopolitanism and cynicism that resulted from the war. depicted in the novel, however, easy money and relaxed social values have corrupted this dream, especially on the East Coast. The main plotline of the novel reflects this assessment, as Gatsby's dream of loving Daisy is ruined by the difference in their respective social statuses, his resorting to crime to make enough money to impress her, and the rampant materialism that characterizes her lifestyle. Thus, This novel portrays materialism in such away which will be discussed in this paper.

\section{Discussion}

So far, I understood that there are The various social climbers and some kinds of approach in literary ambitious speculators who attend Criticism. Personally, I'm not able to Gatsby's parties evidence thegreedy describe all things related with this 
because some ambiguities in my mind related with this knowledge, but I do try to describe simply I known related with literary approaches itself. Those literary criticism approaches are: Here are some approaches in literary criticism; Historical/biographical approach, Moral/philosophical approach, Mimetic approach, Formalism/new criticism,

Mythological/archetypal/symbolic approach, Sociological approach, Marxist approach, Psychological approach, Feminist approach, Structuralism approach. Honestly, I can’t group it well. It just simply I got from my own understanding, but below I will use theories to support that understanding.

Above, I told that, this approach will be materialism approach. This is taken just to compare the theory with the story on it. After I read all the contents of this novel, then I believe that this approach is the proper one to analyze "The Great Gatsby" novel by F. Scott Fitzgerald. Before I go to the analysis, it needs to describe all things related with this approach.

\section{Literature and Sociology}

Sociology derives from the Greek 'Socius' (society) and 'logos' (science) which means the study of all aspects of human and their relation in community (Ratha, 2003:1). Moreover, as stated in Dictionary of Social Sciences (2002: 453), the term of society was first used by Auguste Comte in $1830 \mathrm{~s}$ to propose a synthetic science that would unite all knowledge about human activity. So basically, sociology is a field of knowledge studying about human act and interaction between a human to another. Through sociology, we may figure out the way of human adaptation to the nature, the sociological mechanism of human and other things lead us to the deeper understanding about human.

In general, the object of Sociology is society. A society is a group of humans or other organisms of a single species that is delineated by the bounds of cultural identity, social solidarity, functional and others (http/www.wikipedia.com, accessed onJune 29, 2016). Members of a society maycome from different ethnic groups. A society may be a particular ethnic group, such as the Bataknese or Javanese; a nation state, such an Indonesia; a broader cultural group, such as Eastern society; or even a 
Dida].tid.a Jurnal Pemikiran Penelitian Pendidikan dan Sains

social organism such as an ant colony. According to previous statement, it can be concluded that classification exists in the society since it is a human nature to find the most convenient and right space for them. Then the classification in the society is naturally arranged by the society itself.

A lot of scientists try to explain the relation between literature and society. Karl Marx and Fredrick Engel's in 1848 published their theory about critical analysis of capitalism and a theory of social of change called Marxism. In one of the theory called

"Historical Materialism”, a fundamental underlying reality of human existence: that in order for human beings to survive and continue existence from generation to generation, it is necessary for them to produce and reproduce the material requirements of life (http://en.wikipedia.org/wiki/Marxism, accessed onJune29, 2016). Itis a methodological approach to the study of society, economics, and history. It seems obvious it was Marx's view as the foundation to the understanding of human society and historical development.

\section{Materialism}

As stated in Dictionary of social science (2002: 299), materialism is a philosophical position that states everything is material, or a state of matter. It means that philosophy of materialism holds the only thing that exists is matter; that all things are composed of material and all phenomena (including consciousness) are the result of material interactions. In other words, matter is the only substance.

Many philosophers tried to explain materialistic through science since 19th century since philosophical materialism was developed. A German philosopher, George Wilhelm Friedrich Hegel, found a new scientific philosophy called dialectical materialism. The reality of Hegel' belief was about spirituality and nature as the product consumption. In the other words, Hegel required spiritual happiness as the most important in life.

The young Karl Marx admired this idea of Hegel and convinced that Hegel had discovered something important. He especially admires Hegel's dialectical account of human 
Didadetidea Jurnal Pemikiran Penelitian Pendidikan dan Sains

history into materialism by adapted from the weathers. But by the Hegel's idea by arguing that development of human civilization, economic forces were basic to all they need a lot of needs for their life social phenomena. According to such as variety flavor of food, lavish Marx, production and distribution of house, sophisticated vehicles to ride, or life's necessity should be equal to most fashionable clothes to wear. And people, so there is no gap among society. He claimed equality is the most important thing in society to live better. When Hegel focused on spiritual happiness and Karl Marx developed the idea of materialism more into economic purpose.

Every individual has to work very hard to fulfill their needs and get better living. It is nature of human being to do it, which is why human often called as an economic creature. The goal of economic efforts is the satisfaction of human needs. Everyone requires a minimum of food, clothing and housing as the basic needs of human to survive. Those life's necessitiesshould be got by all people. The production of life's necessities should be enough to all people and the distribution of it should be spread averagely. That is Karl Marx tried to emphasize.

The time is changing and so do the human's needs. In the beginning, they just need food, clothes and shelter to get those things, human need to have a lot of money to buy that. Based on those matters, many people try to get better life to fulfill their needs.

The material as the life's necessities of human changes into prestige of the human himself. Material is no longer interpreted as the life's necessities but it changes into money. It becomes the symbol of success and happiness. This shift process certainly brings a lot of change to the human nature. Material which at the beginning is considered as the life necessities turns into human obsession to reach the happiness.

Modern people started to think money has such a powerful function. With money people do not only get anything they want but also they can also do everything they want to do, Even money involves a human status. Money is a magic power which control human and creates the essential social status (Ratha, 2003:27). It means 
that money is a human's creation which controls them and also the society.

\section{Analysis}

This novel shows material oriented where the goal of economic efforts is the satisfaction of human need. Every human require at least a minimum of clothes, clothing and housing. All physical needs are basic and those things are materials. In the other word, every human is an materialistic creature since they need material as the essential for human survival. But most people prefer variety and many flavor in their food, an comfortable shelter and brand new clothes to wear. People start to concern with desire that go far away beyond the necessities forphysical survival. Human start to behave and think based on material effort to get material success in their life to get happiness and satisfaction. That is the definition of material oriented.

When people are consciously or they do not have material oriented in their life, they will start to lose their humanity because they only care about material matters. An idea that if someone gets material success, they will live happy and can get everything they want since they can buy anything. But it is not everybody can have material success to get better living.

Moral values appear in the society as the direction to create the well ordered of harmony living. Even though some moral values in a society may be different from other but the purpose of it is just the same. People who live in the society should follow it to unity of regularity. It is a direction that leads human into a better person, a dignity as a human being. When human hold on the moral values, they will be a good person with strong moral values as the rule to control the life. In the other hand since human has material oriented in their mind, they will do anything to get it include breaking the rule of moral values.

A fake satisfaction which human gets from material leads them to do anything or sacrifice everything in order to get it. They start not care about moral values as a real human should have. Material oriented only bring human into the dark side of them. But material oriented will bring moral consequence in the same way. In the novel The Great Gatsby, some characters will do anything to 
Didadxtida Jurnal Pemikiran Penelitian Pendidikan dan Sains

get material comforts and do anything for it including against the moral values. As the response of breaking the moral values in order to get material success, it isobvious in the same time human get moral consequence of it. It is moral consequence is lack of moral value in the himself.

Daisy Buchanan, in order to get material comforts, she chose to marrying Tom Buchanan. As a good person with moral values as direction in human's life, it is not right when a person marries someone because of some reason, in this case, material comforts. It is become possible since Daisy is a material oriented person. She cares nothing but material success. It control the way of her thinking and attitude.

Tom and Daisy are married and even have a child but both of them still commit adultery. Daisy is with Tom and Tom is with Myrtle. They both realize that their marriage is empty and unhappy. That is why they try to find happiness with their lovers but the risk of changing their lifestyles is not worthy. They are not happy with their spouses but can not find happiness with their mistress.
Happiness and love can not be bought, no matter how much money is spent. A fake happiness that material can not give guarantee anything but fake and emptiness.

"I'm p- paralyzed with happiness". She laughed again, as if she said something very witty. (P.9)

Daisy expresses her happiness in uncertain expression. She is talking stutter and laughing of her own words. It shows the true feeling of Daisy her self. She is unhappy with her life of marriage. She just tries to convince her self andothers about her feeling. Unfortunately in ironic way when she doubts of her own words.

Jordan Baker, Daisy's friend, realizes the real deep feeling of Daisy's unhappy life. Jordan finds out how empty Daisy in side of her. She believes thatDaisy misses something in her life. That is why she asks Nick Caraway to arrange meeting between Gatsby and Daisy. She believes that it will bring something change in Daisy's empty life.

"Daisy ought to have something in her life" murmured Jordan to me (p.81)

When Daisy meets Jay Gatsby again from such a long time, she surprised to see how success Gatsby with his 
great fortune. She is amaze with "I'm going to fix everything just the Gatsby's property like lavish house, way it was before" he said, nodding clothes and even his yacht. Daisy determinedly. "She'll see" (p.122)

Buchanan is in love with Gatsby because of his wealthy. But she finds out that he is a bootlegger, her love disappeared as sudden as it came. Meanwhile Tom, even has affair him self with Myrtle and other woman, he is so really angry to find out Daisy's affair with Gatsby. Hypocrisy tends to be a trait among rich people. They do have everything but lack of morality and emptiness of their fake life obviously pathetic. Their unhappy life appears as the consequent of their moral degradation.

Jay Gatsby, as the main character of the novel also does the same thing. He becomes a material oriented in order to get his dream, in this case DaisyBuchanan. He does believe when he gets material success, he will win Daisy's heart and starts a new life with her.

"Can't repeat the past?" he cried incredulously. "Why, of course you can!"

He looked at him wildly as if the past were lurking here in shadow of his house, just out of reach of his hand.
Since Gatsby tried hard to get material success in his life in order to win Daisy's heart back, he has become a material oriented because he believes material success will take him to happiness which is being together with Daisy. But the difference between them is Daisy lets material controls her mind'sattitude. In the other hand, Gatsby used material in order to get Daisy's back. Material is only the way of Gatsby to repeat and fix his past with the woman he loves.

But Gatsby's dream is eventually shattered. She attracted and feels in love to Gatsby only because of his material success. Daisy's world is ruled by money. Gatsby is too naive too believe that Daisy has never loved Tom, her husband. He is predicts that he takes advantage of the facts that Gatsby has been separated from Daisy for five years. But in the reality, Daisy admits that she has love Tom and Gatsby in the same time. Daisy is extremely disenchanted after she has found out how Gatsby has acquired his fortune. The fact brings Gatsby 
into deep disappointment. He is too silkblow for mother's grave that'll last naive to believe that Daisy only loves all summer. I got to write down a list so him and he could get Daisy back I won't forget all the things I got to do" because they love each other. He was (p.37) too innocent to believe that he can control things will happen with his material success.

Material comforts and breaking the social discrimination can be the effort of human to do anything. Myrtle Wilson, Tom's mistress attempt to break into the social group of the Buchanan belong is condemned to fail. It is a real fact that social discrimination happen until nowadays and the divisions among people can not be overcome until now. But Myrtle tried to escape from her own class by doing affair with a rich social old background man like Tom. She only becomes vulgar and corrupt like rich. "Most of these fellas will cheat you every time. All they think of is money..." (page 81)

"I'm going to give you this dress as soon as I'm trough with it. I've got to get another one tomorrow. I'm going to make a list of all the things I've got to get. A massage and a wave, and a collar for the dog, and one of those cute little ash- strays where you touch a spring and a wreath with a black

Myrtle Wilson obviously scorns people from her own class and loses all sense of morality as a human being. Even though she tries so hard and sacrifice a lot of things to increase her social status but her attempt to find a place for self into Tom's class never success. It is a fact that when it comes to a crisis, the rich stands together against outsiders. Meanwhile, Myrtle efforts to play the role of society hostess, with her careless gossip and her artificial behavior, hide a desperate desire of her own class. And the fantastic incident when she fights with Tom over her use of Daisy's name contains a hidden warning because it anticipates her death at the hands of Tom and Daisy. It is an irony that even Myrtle sacrifices anything and does things against moral values, she ends in tragic way without success to reach her dream to increase her social status.

\section{Conclusion}

Human needs always develop time to time. At the beginning, human uses material to survive in life. By 
Dida].tid.a Jurnal Pemikiran Penelitian Pendidikan dan Sains

the development of human civilization, human needs variety flavors of food, large convenient house and sophisticated vehicles. People never get enough, they always have something they want to and become greedy. They do anything to get the material success even they have to do things against moral values a human being. It is obviously material possession brings dark side of human itself.

It is ironic because material satisfaction is only empty happiness. Love and happiness still can not be bought even how much money people spent. Human thinks if they have material success, it will give them honor, popularity, achievement and respect from others so they can get happiness. But in the novel The Great Gatsby, Fitzgerald describes some characters who has already had material success but still suffered because they live without love, instead ofmaterial surrounding. They live in such a fake glamorous world which has everything but in reality they have nothing in their life.

\section{References;}

Fitzgerald, F. Scott, 1925. The GreatGastby, 2004. New York: Macmillan Library Reference, USA, Inc.

http/www.wikipedia.com, accessed on June 29, 2016

http://en.wikipedia.org/wiki/Marxism, accessed on June29, 2016

Lange, Friedrich A.,(1925) The History of Materialism. New York, Harcourt, Brace, \& Co.

Ratna, DR.Nyoman Kutha.2003. Paradigma Sosiologi Sastra. Yogyakarta: PustakaPelajar 